\title{
COPING THE ARSENIC TOXICITY IN RICE PLANT WITH MAGNESIUM ADDENDUM FOR ALLUVIAL SOIL OF INDO-GANGETIC BENGAL, INDIA
}

\author{
Sonali PAUL, Rupshali DEY, Ipsita SARKAR, Ankit CHAKRABORTY, Sahil MONDAL, \\ Sreshtha SAHA, Susmita MUKHERJEE*
}

University of Engineering \& Management, Action area III, B/5 New Town, Kolkata 700160, India

Received 30 October 2020; accepted 28 December 2020

\section{Highlights}

It has been experimentally found that:

Dy application of Mg-salt as fertilizer As-induced toxicity can be reduced.

D In As contaminated soil As has got competitive advantage over Mg but application of Mg fertilizer is able to mitigate the problem.

Dg is an important plant nutrient hence there is no extra cost involved and it is an eco-friendly \& economic method.

\begin{abstract}
Arsenic $\left(\mathrm{As}^{3+}\right)$ is a toxic metalloid found in the earth's crust, its elevated concentration is a concern for human health because rice is the staple grain in eastern part of India and the waterlogged rice field environment provides opportunity for more $\mathrm{As}^{3+}$ uptake. Magnesium $\left(\mathrm{Mg}^{2+}\right)$ is an important plant nutrient. Present work is a search for reducing As ${ }^{3+}$ toxicity in plants through $\mathrm{Mg}^{2+}$ application. The findings are quite impressive, the root to shoot biomass ratio showed more than 1.5 times increase compared to the control. Total protein content increased 2 folds. Carbohydrate and chlorophyll content increased two to three times compared to control. On the other hand, Malondialdehyde content showed a decline with the application of increased $\mathrm{Mg}^{2+}$ dose. The in-silico study shows a better interaction with $\mathrm{As}^{3+}$ in presence of $\mathrm{Mg}^{2+}$ but interestingly without stress symptoms. These findings from the research indicate that $\mathrm{Mg}^{2+}$ application can be effective in reducing $\mathrm{As}^{3+}$ induced stress in plants.
\end{abstract}

Keywords: toxicity, in-silico study, oxidative stress, cation competition, environmental sustainability, waste management technologies.

\section{Introduction}

Arsenic $\left(\mathrm{As}^{3+}\right.$ and $\left.\mathrm{As}{ }^{5+}\right)$ is a ubiquitous metalloid found in earth's crust. There is gradual increase in soil $\mathrm{As}^{3+}$ level due to different anthropogenic activities (Chandrakar et al., 2016). It is a non-essential element for plants but depending on the concentration gradient between the source and the sink it is taken up from soil mostly in inorganic forms with the help of various transporter proteins. Among the two oxidation states of $\mathrm{As}^{3+}$ and $\mathrm{As}^{5+}$, the $\mathrm{As}^{5+}$ form is less toxic and is found in immobile mineral form (Shrivastava et al., 2015). The inorganic form of arsenic is more toxic than the organic form.

Sources of $\mathrm{As}^{3+}$ poisoning include agricultural land and urban areas, in countries around the world of which Bangladesh, Pakistan, Nepal, Vietnam, Burma, Thailand and Cambodia are the most affected. Hence $\mathrm{As}^{3+}$ contamination in the environment is considered as a global problem. $\mathrm{As}^{3+}$ stress can affect the growth and productivity of the plants by a plethora of (Singh et al., 2017) physiological and biochemical alterations and the most damaging one is the production of reactive oxygen species (ROS). Plants sometimes develop various tolerance and adaptive mechanisms to cope with stresses which involve a series of physiological and biochemical changes (Khalid et al., 2017). $\mathrm{As}^{3+}$ is also reported to inhibit rate of photosynthesis in plants.

Rice (Oriza sativa $\mathrm{L}$ ) is a potentially important route of human exposure to arsenic as staple food of the people in tropical, subtropical and temperate regions of East Asia. The $\mathrm{As}^{3+}$ in soil can be accumulated by rice plants and can reach to human being through food intake. It has been highlighted that the rice plants are more susceptible for $\mathrm{As}^{3+}$ accumulation because of changing in redox

*Corresponding author. E-mail: susmita.mukherjee@iemcal.com 
condition during flooding condition in the paddy fields (Ma, 2001). In case of cultivation in a large area with moderately $\mathrm{As}^{3+}$ infested soil it is difficult to remove soil $\mathrm{As}^{3+}$. Phytoremediation is practised as an eco-friendly and the most economic remediation technique. This technique is dependent on many environmental parameters and under best possible conditions (Chaudhry et al., 2002) also the efficiency is limited. Another major concern for phytoremediation is the proper disposal of the huge contaminated biomass generated.

$\mathrm{Mg}^{2+}$ is the second most important nutrient for the plants and is part of large numbers of metabolic pathways. According to Cakmak and Yazici (2010), Chloroplast in plants contains $31 \%$ of the total $\mathrm{Mg}^{2+}$ content; it is required for chlorophyll formation and plays a key role in photosynthetic activity. Wingler et al. (2005) explained that under Mg-deprivation due to a reduction in electron transport, chlorosis takes place in plants, which impairs $\mathrm{CO}_{2}$ fixation and induces generation of Reactive Oxygen species (ROS). These can cause damage of cell components, like membrane lipids, proteins, and nucleic acids, resulting in metabolic disruption (Scandalios, 2005). An increased activity of antioxidant defense enzymes has been reported in some plant species under Mg-deficient conditions (Tewari et al., 2005; Shulaev et al., 2008).

The importance of $\mathrm{Mg}^{2+}$ in crop production was well estimated only in the last decade (Cakmak \& Yazici, 2010), agronomists and scientists have paid little attention to this mineral nutrient compared to others. There are prominent reasons for $\mathrm{Mg}^{2+}$ deficiency to occur in plants, among them, the effects of cation competition $\left(\mathrm{Ca}^{2+}, \mathrm{K}^{+}\right.$ and $\mathrm{Na}^{+}$) were found to be significant (Broadley \& White, 2010) which is further accelerated with addition of 'N-P$\mathrm{K}$ ' fertilizer without adding $\mathrm{Mg}^{2+}$. Hence in the cultivation process without using $\mathrm{Mg}^{2+}$ fertilizer, there is enough reason for $\mathrm{Mg}^{2+}$ deficiency in the plants.

From the above discussions it is understandable that soil $\mathrm{As}^{3+}$ in plants adversely affects various metabolic processes which are manifested as stress symptoms in plants. $\mathrm{Mg}^{2+}$ regulates a lot of metabolic activities in plants and its deficiency also causes stress symptoms. All these factors corroborate the scientific fact that $\mathrm{Mg}^{2+}$ in plants can be helpful in reducing physiological and biochemical problems. In addition, $\mathrm{Mg}^{2+}$ uptake by plants gets adversely affected due to cation competition and it indicates requirement of additional magnesium fertilizer in the cultivation process.

Under such condition the objectives of this present study are to (i) understand the most effective role of soil
$\mathrm{Mg}^{2+}$ fertilizer in reducing As induced stresses in rice plants, (ii) highlight the nature of transporter proteins involve in the competitive uptake (iii) propose an ecofriendly and economic process for remediation of As toxicity in rice plants.

\section{Materials and method}

\subsection{Criteria of selection of Plant species}

Rice being the staple consumed form of carbohydrate in Indo-Gangetic plains which is recognised as a potential source of $\mathrm{As}\left(\mathrm{As}^{3+}\right)$ contamination from various studies (Ma, 2001). The rice plants are more susceptible to As $\left(\mathrm{As}^{3+}\right)$ contamination due to favourable changes of physico-chemical condition of soil during its growth and it can be the easiest way to human contamination through food consumption. Thus rice is chosen as the experimental plant in the present study. It is a monocot plant belongs to the Gramineae family and the genus Oryzae and the plant variety used for the experiment was Shatabdi (IET4786). Experimental set-up was done in September 2019 and harvesting was in January 2020 and the testing of parameters was done during January-February 2020.

\subsection{Setting up of the experiment}

The rice seed, collected from Rice Research Station, Chinsurah, West Bengal were allowed to germinate in a pot and 8-10 days old seedlings were first sown, then these were transplanted after another 15 days into a total of 12 different pots comprising of one control and three experimental sets, each in triplicate (Table 1). Each pot had $3 \mathrm{Kg}$ of soil with a definite amount of magnesium $\left(\mathrm{Mg}^{2+}\right.$ salt, magnesium carbonate) and Arsenic ( $\mathrm{As}^{3+}$ salt, sodium arsenite) addendum in addition 2 gms of compost was added in each pot in divided dose as fertilizer for normal growth of the plants. The rice seedlings were added uniformly in a ratio of 10 seedlings per pot and the plants were grown till the panicle stage. All settings were done in triplicate and the results were represented as an average.

An in-silico study was performed to have idea on the transporter proteins involvement in the competitive transportation process. A molecular docking study was done to understand the protein-ligand interaction. Previous to the docking interaction studies, the 3D structure of the root transport protein of Oryza sativa (PDB ID 6OCE) was selected (Maity et al., 2019). The protein that was taken into consideration was a hypothetical transporter protein that was determined using the X-ray crystallographic studies.

Table 1. Showing experimental set-up: pots with different addendum

\begin{tabular}{|c|l|l|}
\hline Sl No. & \multicolumn{1}{|c|}{ Pot marking } & \multicolumn{1}{c|}{ Addendum } \\
\hline 1 & C - Control & $\mathrm{As}^{3+}(30 \mathrm{mg} / \mathrm{kg})$ without $\mathrm{Mg}^{2+}$ \\
\hline 2 & Experimental-1 (E1) & $\mathrm{Mg}^{2+}(5.5 \mathrm{gm} / \mathrm{kg})+\mathrm{As}^{3+}(30 \mathrm{mg} / \mathrm{kg})$ \\
\hline 3 & Experimental-2 (E2) & $\mathrm{Mg}^{2+}(6.5 \mathrm{gm} / \mathrm{kg})+\mathrm{As}^{3+}(30 \mathrm{mg} / \mathrm{kg})$ \\
\hline 4 & Experimental-3 (E3) & $\mathrm{Mg}^{2+}(7.5 \mathrm{gm} / \mathrm{kg})+\mathrm{As}^{3+}(30 \mathrm{mg} / \mathrm{kg})$ \\
\hline
\end{tabular}




\subsection{Estimation of soil $\mathrm{pH}$}

The $\mathrm{pH}$ of soil sample was measured in soil solution with dilution ratio of soil: solution as 1:2.5. The samples were equilibrated to the normal temperature. The $\mathrm{pH}$ was measured by digital $\mathrm{pH}$ meter (model no. Systronics-802) after standardisation, soil $\mathrm{pH}$ was tested as $7( \pm 0.2)$.

\subsection{Estimation of malondialdehyde content}

The sample extract was prepared by grinding the fresh plant sample followed by centrifugation and collecting the supernatant. In the supernatant $20 \%$ TCA (Trichloroacetic Acid) and 0.5\% TBA (Thiobarbituric acid) were added and mixed well. The mixture was boiled and then quickly cooled on ice and then centrifuged. The supernatant was collected and the absorbance was recorded at $532 \mathrm{~nm}$. The concentrations were calculated by graphical plotting against a standard curve using different concentrations of malondialdehyde (Zhang \& Huang, 2013).

\subsection{Estimation of total chlorophyll content}

The fresh plant samples were ground in liquid nitrogen using acetone and supernatant was collected for preparation of the sample extract. This procedure was repeated till the residue becomes colourless. The absorbance was measured by colorimeter (Digital Photo Colorimeter, model No. LT-12, LABTRONICS) at $645 \mathrm{~nm}, 663 \mathrm{~nm}$ to calculate the chlorophyll concentration (Sadasivam \& Manickam, 2008).

\subsection{Estimation of total carbohydrate}

The fresh samples were acid digested and then neutralized with sodium carbonate and centrifuged. To the supernatant anthrone was added, boiled, cooled and the absorbance (Digital Photo Colorimeter, model No. LT-12, LABTRONICS) recorded at $630 \mathrm{~nm}$. The concentrations were calculated by graphical plotting against a standard curve using different concentrations of standard glucose (Sadasivam \& Manickam, 2008).

\subsection{Estimation of total protein}

The fresh plant samples were ground followed by centrifugation and supernatant collected. To this extract alkaline copper solution was added and mixed well followed by addition of Folin - ciocalteau reagent, mixed well and incubated in the dark for $30 \mathrm{~min}$. The absorbance was measured at $660 \mathrm{~nm}$ (Digital Photo Colorimeter, model No. LT12, LABTRONICS). The concentrations were calculated by graphical plotting against a standard curve using different concentrations of bovine serum albumin (Sadasivam \& Manickam, 2008).

\subsection{Docking interaction study}

Ligand dependent protein docking was performed using the Lamarckian Genetic Algorithm (LGA) method.
Standard docking settings were applied and the energetically most favourable binding poses (lowest docked energy) were taken to obtain the best conformation. The prediction was done using Auto-Dock-Vina software. The docking interaction studies were performed between the transport protein, Arsenic $\left(\mathrm{As}^{3+}\right)$ and Magnesium $\left(\mathrm{Mg}^{2+}\right)$. The unwanted water molecules that were present in the protein was separated and the protein was stabilized at $\mathrm{pH} 7( \pm 0.2)$. The most stable conformation of the determined structures of the prepared ligand as predicted was selected to flexibly dock against the created receptor grid. The interaction was studied under "Ligand interaction diagram" and the types of interaction and bond lengths were predicted. Finally, the interaction of the metal with amino acid was performed using Ligplot.

\subsection{Statistical significance}

The experimental results were analyzed by using paired $\mathrm{T}$ test following standard statistical methods and the data were subjected to estimate significant level. Only the $\mathrm{p}<$ 0.05 or 0.01 was considered and were shown in the figures. Descriptive statistics including mean, average, standard deviation and standard error were considered to represent the precision of the analysis. All results showed more than $90 \%$ confidence level.

\section{Results and discussion}

In the present study, different biochemical plant parameters were assessed to understand the $\mathrm{As}^{3+}$ induced toxicity at cellular level in the rice plants and the role of $\mathrm{Mg}^{2+}$ in mitigating the same. Also through in silico study the interaction of the transporter protein with $\mathrm{As}^{3+}$ and $\mathrm{Mg}^{2+}$ was observed. It has been reported that $\mathrm{As}^{3+}$ has a negative impact on plant biomass. Hence to understand the effect of $\mathrm{As}^{3+}$ on the plant biomass and also the contribution of $\mathrm{Mg}^{2+}$ in it, the root to shoot biomass ratio was studied.

\subsection{Comparison of plant root to shoot growth}

In the experimental result as shown in Figure 1 the control plant with only $\mathrm{As}^{3+}$ dose and no $\mathrm{Mg}^{2+}$ the root to shoot biomass ratio was quite low, where as in the plants with

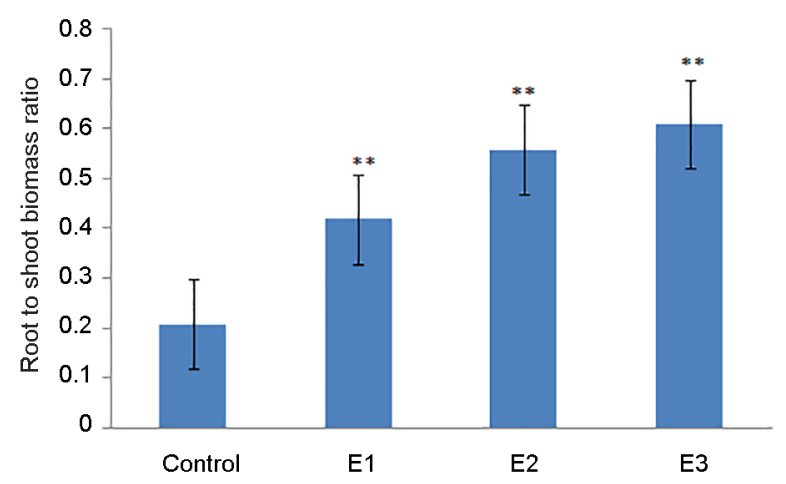

Figure 1. Comparison of changes in root to shoot biomass ratio in the experimental plants 
application of different doses of $\mathrm{Mg}^{2+}$ the root to shoot biomass ratio was increased gradually with increase of $\mathrm{Mg}^{2+}$ dose. At higher concentration $\mathrm{As}^{3+}$ is toxic for almost all plants and reduces growth of both root and shoot, depresses tillering (Abedin et al., 2002). In many research works it has also been reported that $\mathrm{Mg}^{2+}$ deficiency in plants causes decrease in root to shoot biomass ratio (Cakmak et al., 1994a, 1994b; Mengutay et al., 2013).

In a study by Farhat et al. (2016) it was reported that magnesium fertilization increases total plant biomass by $61 \%$ compared to $\mathrm{Mg}^{2+}$ deficient control plants (Farhat et al., 2016). The positive effect of magnesium fertilization on the root biomass (77\%) was greater than the shoot biomass (59\%) as described by da Silva et al. (2014). The experimental results (Figure 2) also showed a considerable increase in root lengths with increased doses of $\mathrm{Mg}^{2+}$ fertilizer compared to the control plant with only $\mathrm{As}^{3+}$ and no $\mathrm{Mg}^{2+}$.

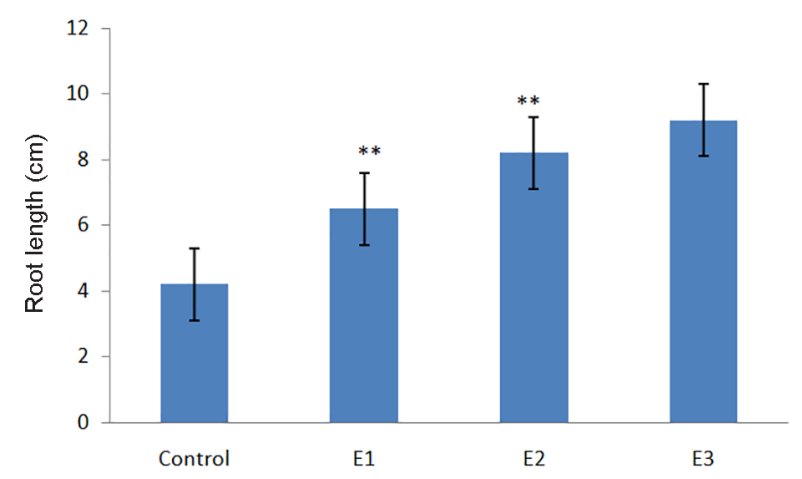

Figure 2. Comparison of root length between the experimental plants and control

\subsection{Plant stress parameters}

In general, exposure to $\mathrm{As}^{3+}$ reduces chlorophyll and protein content and photosynthetic activity in plants (Marin et al., 1993). In plants photosynthetic limitation results in reduced capacity for biochemical utilization of absorbed light energy which induces the formation of reactive oxygen species (ROS) such as superoxide radicals and hydrogen peroxide (Hauer-Jákli \& Tränkner, 2019). In the

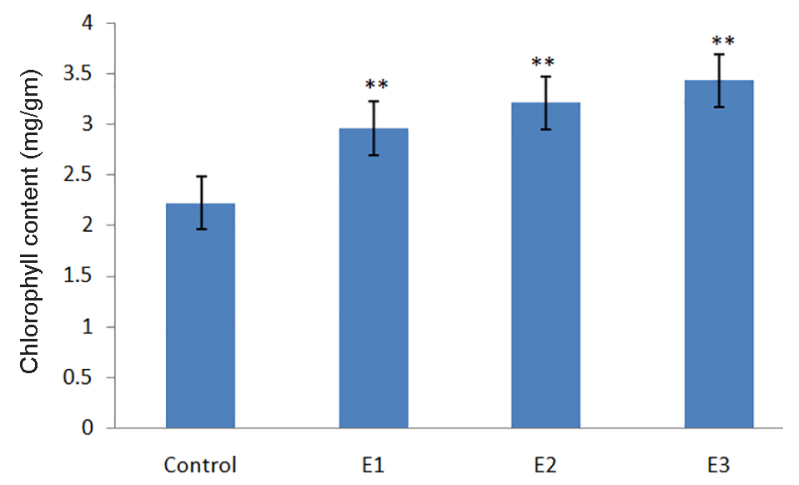

Figure 3. Change in Chlorophyll content in the experimental plants present work the $\mathrm{Mg}^{2+}$ deficient and only $\mathrm{As}^{3+}$ exposed control plants showed less chlorophyll content (Figure 3) compared to the plants with $\mathrm{Mg}^{2+}$ application where total chlorophyll content had increased significantly.

It has been reported that $\mathrm{Mg}^{2+}$ directly affects the activity of Rubisco enzyme and activation by binding to the carbamylated Rubisco side chain (Hazra et al., 2015) and $\mathrm{Mg}^{2+}$ supply significantly enhances net photosynthetic $\mathrm{CO}_{2}$ assimilation compared to the plants with $\mathrm{Mg}^{2+}$ deficiency. In the present study, photosynthetic $\mathrm{CO}_{2}$ assimilation was confirmed in terms of increased carbohydrate production with the increase in $\mathrm{Mg}^{2+}$ dose (Figure 4).

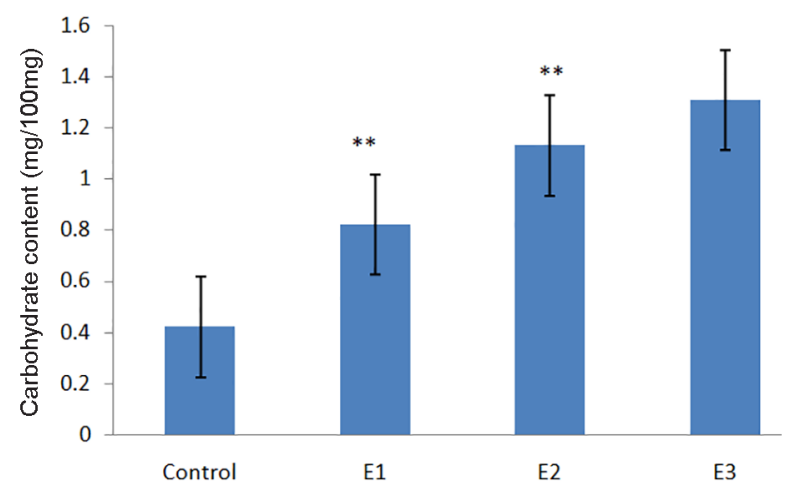

Figure 4. Change in Carbohydrate content in the experimental plants

Malondialdehyde (MDA) accumulation was reported in rice (Ding et al., 2008), as a general indicator of lipid peroxidation under low $\mathrm{Mg}^{2+}$ availability conditions. According to the study conducted by Hauer-Jákli and Tränkner (2019), the levels of ROS increased by $31 \%$ under $\mathrm{Mg}^{2+}$ deficiency. In the work by Kobayashi et al. (2018) there was an increased level of oxidative stress in $\mathrm{Mg}^{2+}$ deficient rice plants. MDA is an important by product of lipid-peroxidation during oxidative stress. Hence sufficient $\mathrm{Mg}^{2+}$ supply is required for plants to reduce oxidative stress. It is also been reported that $\mathrm{As}^{3+}$ causes oxidative stress in plants. In the present study, MDA content analysis also showed a similar trend (Figure 5). The control sample with only $\mathrm{As}^{3+}$ exposure had shown maximum stress in terms of highest MDA content. However,

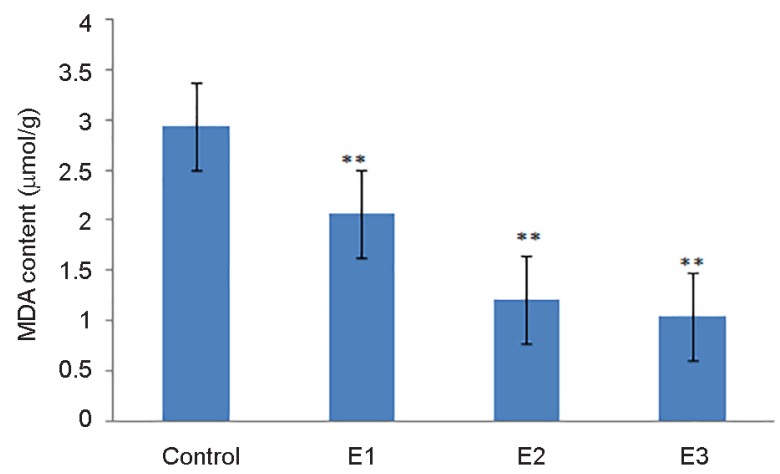

Figure 5. Change in MDA content among the experimental plants 
with increasing $\mathrm{Mg}^{2+}$ fertilizer dose, MDA content had decreased considerably. Hence, it could be hypothesized that $\mathrm{Mg}^{2+}$ might have played some positive roles in rice plants to withstand the increment of MDA.

Studies on rice plant have shown that magnesium $\left(\mathrm{Mg}^{2+}\right)$ has a significant impact on the nutritional quality of rice. With sufficient magnesium $\left(\mathrm{Mg}^{2+}\right)$ supply in rice plant the total protein content significantly increases. It has also been observed in brown rice that total amino acids is increased and the contents of two kinds of limiting amino acids, lysine and threonine, of cereal protein is also increased leading to improvement of the nutritional quality of the produce (Ding, 2002). The experimental results (Figure 6) showed that the control plants with only $\mathrm{As}^{3+}$ treatment had minimum protein content but with increased $\mathrm{Mg}^{2+}$ content in other plants the protein content had increased which corroborate the findings by previous researchers.

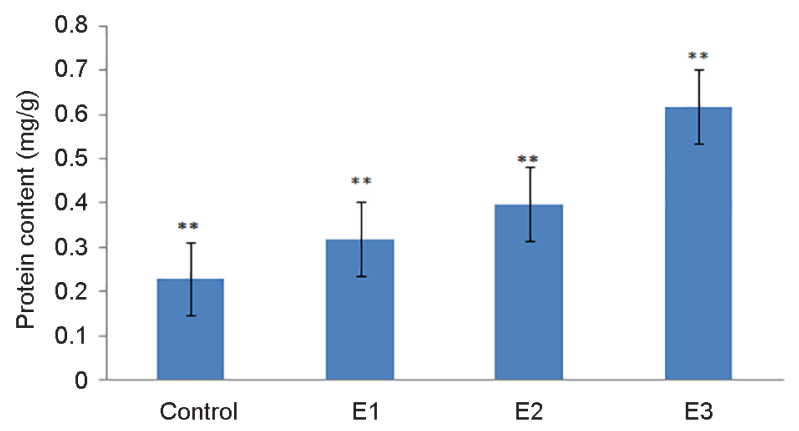

Figure 6. Comparison of protein content in different experimental plants

\subsection{Molecular interaction study}

The docking interaction studies between 6OCE protein with both $\mathrm{As}^{3+}$ and $\mathrm{Mg}^{2+}$ showed the value -1.37 and $-1.31 \mathrm{Kcal} / \mathrm{mol}$ respectively, it seems that the interaction with $\mathrm{As}^{3+}$ was slightly better. It was further observed that in the presence of $\mathrm{Mg}^{2+}$, the uptake of As was increased as
Table 2. Molecular interaction between transport protein with $\mathrm{As}^{3+}$ and $\mathrm{Mg}^{2+}$ ions

\begin{tabular}{|l|c|l|}
\hline \multicolumn{1}{|c|}{ Interaction } & $\begin{array}{c}\text { Binding } \\
\text { energy } \\
\text { (Kcal/mol })\end{array}$ & \multicolumn{1}{|c|}{ Amino acid } \\
\hline Arsenic vs 6OCE & -1.37 & Tyr 356, Leu 456 \\
\hline $\begin{array}{l}\text { Magnesium vs } \\
\text { 6OCE }\end{array}$ & -1.31 & $\begin{array}{l}\text { Phe 469, Phe 473, Val 472, } \\
\text { Asn 471, Gly 475, Leu 474 }\end{array}$ \\
\hline $\begin{array}{l}\text { Magnesium vs } \\
\text { 6OCE vs Arsenic }\end{array}$ & -1.39 & $\begin{array}{l}\text { With Magnesium: Val 472, } \\
\text { Gly 475, Phe 469 } \\
\text { With Arsenic: Tyr 356, Leu } \\
\text { 456, Ala 570 }\end{array}$ \\
\hline
\end{tabular}

the value of binding interaction was enhanced from -1.37 to $-1.39 \mathrm{Kcal} / \mathrm{mol}$ (Figure $7 \mathrm{c}$ ).

The ligplot revealed the stable interactions of $\mathrm{Mg}^{2+}$ and $\mathrm{As}^{3+}$ with transport protein via hydrogen bond as represented in Figure 7 and Table 2. It is interesting to highlight that although $\mathrm{As}^{3+}$ ion had shown competitive advantage over $\mathrm{Mg}^{2+}$ in O. sativa, but without effecting the plant which is justified from the biochemical parameters and it is possible because of application of $\mathrm{Mg}^{2+}$ fertilizer (Thakur et al., 2020; Gransee \& Führs, 2013) in the cultivation process.

\subsection{Implication of the work}

Arsenic is a toxic metalloid naturally present in the soil. Rising soil As concentration is a major concern around the globe due to the health risk to plants, animals and human beings. Rice is the staple food in eastern part of India and soil Arsenic is a major concern here. The waterlogged field condition in rice cultivation makes it more prone to $\mathrm{As}^{3+}$ uptake. $\mathrm{Mg}^{2+}$ is an important macro nutrient required for normal growth of the plant. In the work we have found that adding $\mathrm{Mg}^{2+}$ along with commercial fertilizer (in this case 'N-P-K') improves health of the plant as well as reduces $\mathrm{As}^{3+}$ induced stress. Hence it can be an eco-friendly and sustainable solution to the global agricultural problem.
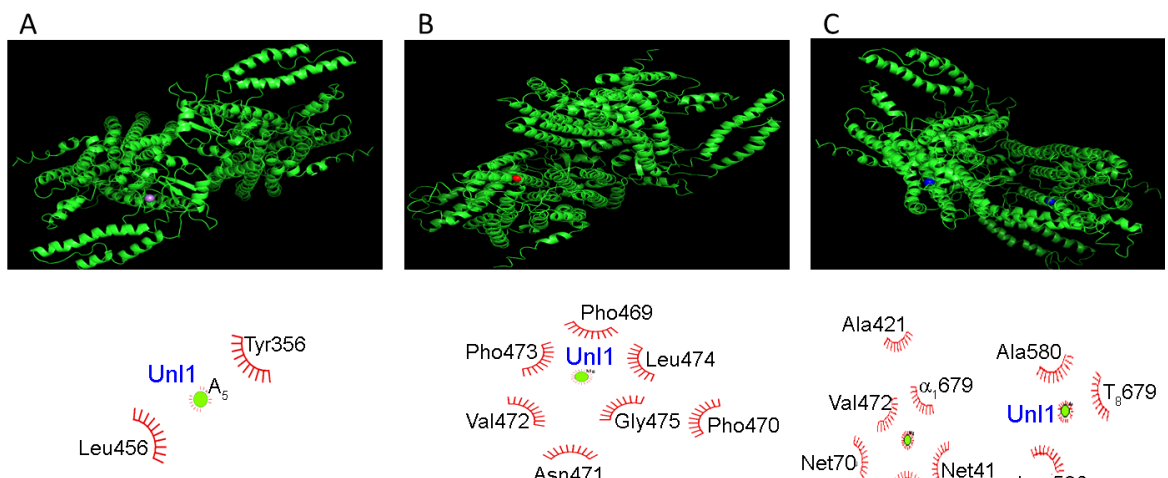

complex
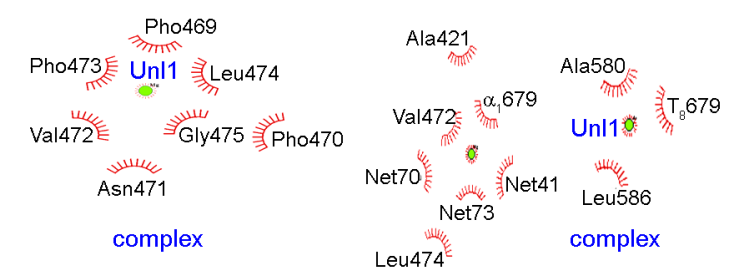

Note: Text marked in blue represents reviewers (both reviewer 1 and reviewer 3) comments.

Figure 7. Molecular interaction of transport protein of O. sativa (6OCE) (A) $\mathrm{As}^{3+}$ (B) $\mathrm{Mg}^{2+}(\mathrm{C})$ Synergistic interaction of $\mathrm{Mg}^{2+}$ and $\mathrm{As}^{3+}$ 


\section{Conclusions}

The purpose of this work was to understand how the application of $\mathrm{Mg}^{2+}$ could be effective in reducing the $\mathrm{As}^{3+}$ toxicity in plants. In the present study, the docking interaction between $\mathrm{As}^{3+}$ and $\mathrm{Mg}^{2+}$ with the transporter protein revealed that plants accumulated a lower amount of $\mathrm{Mg}^{2+}$ compared to $\mathrm{As}^{3+}$ (Figure 7c). From the analysis of all the biochemical parameters, it could be concluded that the application of $\mathrm{Mg}^{2+}$ fertilizer showed effectiveness in reducing $\mathrm{As}^{3+}$ induced toxicity. Interestingly though the docking interaction showed more uptake of $\mathrm{As}^{3+}$ compared to $\mathrm{Mg}^{2+}$ but the biochemical parameters showed less stress in plants. This may be due to added $\mathrm{Mg}^{2+}$ doses, which led us to forecast that $\mathrm{Mg}^{2+}$ can act as a toxicity reducer for As contaminated plants. Further work in this direction might be employed to ascertain the optimum application of $\mathrm{Mg}^{2+}$ fertilizer in order to represent the best performances.

\section{Conflict of interest}

The authors do not have any conflict of interest in publication of this work.

\section{Acknowledgements}

The authors are indebted to the management of University of Engineering \& Management, Kolkata for providing the financial assistance for this research.

\section{References}

Abedin, M. J., Cottep-Howells, J., \& Meharg, A. A. (2002). Arsenic uptake and accumulation in rice (Oryza sativa L.) irrigated with contaminated water. Plant and Soil, 240, 311-319. https://doi.org/10.1023/A:1015792723288

Broadley, M. R., \& White, P. J. (2010). Eats roots and leaves. Can edible horticultural crops address dietary calcium, magnesium and potassium deficiencies? The Proceedings of the Nutrition Society, 69, 601-612.

https://doi.org/10.1017/S0029665110001588

Cakmak, I., Hengeler, C., \& Marschner, H. (1994a). Partitioning of shoot and root dry matter and carbohydrates in bean plants suffering from phosphorus, potassium and magnesium deficiency. Journal of Experimental Botany, 45, 1245-1250. https://doi.org/10.1093/jxb/45.9.1245

Cakmak, I., Hengeler, C., \& Marschner, H. (1994b). Changes in phloem export of sucrose in leaves in response to phosphorus, potassium and magnesium deficiency in bean plants. Journal of Experimental Botany, 45, 1251-1257. https://doi.org/10.1093/jxb/45.9.1251

Cakmak, I., \& Yazici, A. M. (2010). Magnesium: a forgotten element in crop production. Better Crops with Plant Food, 94(2), 23-25.

Chandrakar, V., Naithani, S. C., \& Keshavkant, S. (2016). Arsenic-induced metabolic disturbances and their mitigation mechanisms in crop plants: A review. Biologia, 71, 367-377. https://doi.org/10.1515/biolog-2016-0052

Chaudhry, Q. Schröder, P., Werck-Reichhart, D., Grajek, W., \& Marecik, R. (2002). Prospects and limitations of phytoreme- diation for the removal of persistent pesticides in the environment. Environmental Science and Pollution Research, 9, 4. https://doi.org/10.1007/BF02987313

da Silva, D. M., Brandão, I. R., Alves, J. D., de Santos, M. O., de Souza, K. R. D., \& de Silveira, H. R. O. (2014). Physiological and biochemical impacts of magnesium-deficiency in two cultivars of coffee. Plant and Soil, 382, 133-150. https://doi.org/10.1007/s11104-014-2150-5

Ding, Y. C., Chang, C. R., Luo, W., Wu, Y. S., Ren, X. L., Wang, P., $\& \mathrm{Xu}, \mathrm{G} . \mathrm{-H}$. (2008). High potassium aggravates the oxidative stress induced by magnesium deficiency in rice leaves. Pedosphere, 18(3), 316-327. https://doi.org/10.1016/S1002-0160(08)60021-1

Ding, Q. (2002). Exchangeable magnesium content in soil and effect of magnesium on soybeannutrition along the Huaihe River in Anhui province. Anhui Agricultural Science Bulletin, $8(6), 60-62$.

Farhat, N., Elkhouni, A., Zorrig, W., Smaoui, A., Abdelly, C., \& Rabhi, M. (2016). Effects of magnesium deficiency on photosynthesis and carbohydrate partitioning. Acta Physiologie Plantarum, 38, 145. https://doi.org/10.1007/s11738-016-2165-Z

Gransee, A., \& Führs, H. (2013). Magnesium mobility in soils as a challenge for soil and plant analysis, magnesium fertilization and root uptake under adverse growth conditions. Plant and Soil, 368, 5-21. https://doi.org/10.1007/s11104-012-1567-y

Hauer-Jákli, M., \& Tränkner, M. (2019). Critical leaf magnesium thresholds and the impact of magnesium on plant growth and photo-oxidative defense: A systematic review and meta analysis from 70 years of research. Frontiers in Plant Science, 10, 766. https://doi.org/10.3389/fpls.2019.00766

Hazra, S., Henderson, J. N., Liles, K., Hilton, M. T., \& Wachter, R. M. (2015). Regulation of ribulose-1,5-bisphosphate carboxylase/oxygenase (Rubisco) activase: Product inhibition, cooperativity, and magnesium activation. Journal of Biological Chemistry, 290, 24222-24236. https://doi.org/10.1074/jbc.M115.651745

Khalid, S., Shahid, M., Niazi, N. K., Rafiq, M., Bakhat, H. F., Imran, M., Abbas, T., Bibi, I., \& Dumat, C. (2017). Arsenic behaviour in soil-plant system: Biogeochemical reactions and chemical speciation influences. In Enhancing cleanup of environmental pollutants (pp. 97-140). Springer. https://doi.org/10.1007/978-3-319-55423-5_4

Kobayashi, N. I., Ogura, T., Takagi, K., Sugita, R., Suzuki, H., Iwata, R., Nakanishi, T. M., \& Tanoi, K. (2018). Magnesium deficiency damages the youngest mature leaf in rice through tissue specific iron toxicity. Plant and Soil, 428, 137-152. https://doi.org/10.1007/s11104-018-3658-x

Ma, L. Q., Komart, K. M., Tu, C., Zhang, W., Cai, Y., \& Kennelley, E. D. (2001). A fern that hyperaccumulates arsenic. Nature, 409, 579. https://doi.org/10.1038/35054664

Maity, K., Heumann, J. M., McGrath, A. P., Kopcho, N. J., Hsu, P. K., Lee, C. W., Mapes, J. H., Garza, D., Krishnan, S., Morgan, G. P., Hendargo, K. J., Klose, T., Rees, S. D., Medrano-Soto, A., Saier Jr M. H., Piñeros, M., Komives, E. A., Schroeder, J. I., Chang, G., \& Stowell, M. H. B. (2019). CryoEM structure of OSCA1.2 from Oryza sativa elucidates the mechanical basis of potential membrane hyperosmolality gating. PNAS, 116(28), 14309-14318. https://doi.org/10.1101/505453

Marin, A. R., Pezeshki, S. R., Masscheleyn, P. H., \& Choi, H. S. (1993). Effect of dimethylarsinic acid (DMAA) on growth, tissue arsenic and photosynthesis of rice plants. Journal of Plant Nutrion, 16(5), 865-880. https://doi.org/10.1080/01904169309364580 
Mengutay, M., Ceylan, Y., Kutman, U. B., \& Cakmak, I. (2013). Adequate magnesium nutrition mitigates adverse effects of heat stress on maize and wheat. Plant and Soil, 368, 57-72. https://doi.org/10.1007/s11104-013-1761-6

Sadasivam, S., \& Manickam, A. (2008). Biochemical methods. New Age International (P) Ltd. Publishers, New Delhi, India.

Shrivastava, A., Ghosh, D., Dash, A., \& Bose, S. (2015). Arsenic contamination in soil and sediment in India: Sources, effects, and remediation. Current Pollution Reports, 1, 35-46. https://doi.org/10.1007/s40726-015-0004-2

Shulaev, V., Cortes, D., Miller, G., \& Mittler, R. (2008). Metabolomics for plant stress response. Physiologia Plantarum, 132, 199-208. https://doi.org/10.1111/j.1399-3054.2007.01025.x

Singh, A. P., Dixit, G., Kumar, A., Mishra, S., Kumar, N., Dixit, S., Singh, P. K., Dwivedi, S., Trivedi, P. K., \& Pandey, V. (2017). A protective role for nitric oxide and salicylic acid for arsenite phytotoxicity in rice (Oryza sativa L.). Plant Physiology and Biochemistry, 115, 163-173.

https://doi.org/10.1016/j.plaphy.2017.02.019

Scandalios, J. G. (2005). Oxidative stress: molecular perception and transduction of signals triggering antioxidant gene de- fenses. Brazilian Journal of Medical and Biological Research, 38, 995-1014. https://doi.org/10.1590/S0100-879X2005000700003

Tewari, R. K., Kumar, P., \& Sharma, P. N. (2006). Magnesium deficiency induced oxidative stress and antioxidant responses in mulberry plants. Scientia Horticulturae, 108(1), 7-14. https://doi.org/10.1016/j.scienta.2005.12.006

Thakur, S., Choudhary, S., Majeed, A., Singh, A., \& Bhardway, P. (2020). Insights into the molecular mechanism of arsenic phytoremediation. Journal of Plant Growth Regulation, 39, 532-543.

https://doi.org/10.1007/s00344-019-10019-w

Wingler, A., Brownhill, E., \& Pourtau, N. (2005). Mechanisms of the lightdependent induction of cell death in tobacco plants with delayed senescence. Journal of Experimental Botany, 56, 2897-2905. https://doi.org/10.1093/jxb/eri284

Zhang, Z., \& Huang, R. (2013). Analysis of malondialdehyde, chlorophyll proline, soluble sugar, and glutathione content in arabidopsis seedling. Bioprotocol, 3(14), 1-8.

https://doi.org/10.21769/BioProtoc.817 